\title{
TINJAUAN YURIDIS TERHADAP PEREDARAN COMPACT DISK (CD) BAJAKAN DI KOTA BATAM
}

\author{
Pristika Handayani \\ Program Studi Ilmu Hukum, Fakultas Hukum, Universitas Riau Kepulauan, Indonesia \\ handayanipristika@yahoo.com
}

\begin{abstract}
Abstrak
Peredaran CD bajakan salah satunya sangat marak dan mudah didapatkan, termasuk di kaki lima atau pinggir jalan. Ketimpangan harga menjadi salah satu penyebab maraknya pembajakan CD, komsumen yang hendak menikmati dengan harga murah akan lebih tertarik untuk membeli daipada harus membeli yang asli atau original, sehingga memacu para pembajak untuk memperbanyak CD bajakan. Undang-Undang HKI yaitu No. 28 Tahun 2014 dan kitab Undang-Undang Hukum Pidana menjadi salah satu solusi untuk pencegahan akan terjadinya penyalahgunaan hak cipta.

Kata kunci: bajakan, pencegahan, konsumen.
\end{abstract}

\begin{abstract}
Pirated CD circulation is very lively and easily available, including on the sidewalk or on the roadside. Inequality in price is one of the causes of the rise of piracy CDs, consumers who want to enjoy at a low price will be more interested in buying than having to buy the original or original, thus spurring the hijackers to reproduce pirated CDs. IPR Law No. 28 of 2014 and the book Criminal Law is one solution to prevent the occurrence of copyright abuse.

Keywords: pirated, prevention, consumers.
\end{abstract}




\section{PENDAHULUAN}

Hak asasi manusia merupakan hak fundamental yang dimiliki oleh setiap orang sejak dikandungan, dilahirkan dan menjalani kehidupannya, hingga ia meninggal dunia. Dalam menjalani kehidupannya, setiap orang memiliki kemampuan untuk berkreasi guna memenuhi kebutuhan akan eksistensi dirinya, secara umum Pasal 33 Undang-undang Dasar 1945 mengatur mengenai penguasaan negara terhadap perekonomian dan kesejahteraan sosial.

Seperti yang tercantum di Pasal 33 ayat (3) Undang-Undang Dasar 1945 yang menyatakan bahwa Perekonomian nasional diselenggarakan berdasarkan atas demokrasi ekonomi dengan prinsip kebersamaan, efisiensi berkeadilan, berkelanjutan, berwawasan lingkungan, kemandirian, serta dengan menjaga keseimbangan kemajuan dan kesatuan ekonomi nasional.

Salah satu wujud dari pemenuhan kebutuhan hidup dasarnya adalah dengan berkreasi sehingga menghasilkan suatu karya cipta tersendiri yang unik dari masing-masing orang. Mengenai jaminan akan pemenuhan hak setiap orang untuk memenuhi kebutuhan kehidupan dasarnya ini secara tegas dinyatakan dalam Pasal 5 ayat (1), Pasal 20 ayat (1), Pasal 28C ayat (1), dan Pasal 33 Undang-undang Dasar 1945. Atas dasar Pasal inilah, maka diterbitkan UU No. 28 Tahun 2014 tentang Hak Cipta, agar undang-undang ini dipatuhi dan ditaati oleh masyarakat.

Keberadaan undang-undang ini tentunya memberikan sebuah dimensi tugas baru bagi Kepolisian sebagai salah satu bagian dari Criminal Justice System terutama dalam upayanya melakukan penegakan hukum dibidang perlindungan Hak Cipta. Semakin mudahnya penggandaan dalam hal ini adalah CD (compact disk) maka kejahatan pun semakin mudah, penggandaan merupakan pelanggaran yaitu termasuk dalam tindak pidana.

Jual beli adalah kegiatan yang tidak asing dilakukn oleh masyarakat. Salah satu kemajuan suatu Negara bisa berkembang atau tidak dapat dilihat dari pesatnya jual beli atau perekonomian yang tumbuh di masyarakat. Ketika perekonomian itu maju artinya jual beli ramai dan berjalan maka Negara juga akan berkembang. Salah satu penjualan yang ramai berkeliaran di masyarakat adalah penjualan CD (compact disk). Semakin maraknya peredaran CD sehingga semakin mudahnya konsumen untuk mendapatkan. Peredaran CD bajakan salah satunya sangat marak dan mudah didapatkan, termasuk di kaki lima atau pinggir jalan. Ketimpangan harga menjadi salah satu penyebab maraknya pembajakan CD, komsumen yang hendak menikmati dengan harga murah akan lebih tertarik untuk membeli daipada harus 
membeli yang asli atau original, sehingga memacu para pembajak untuk memperbanyak CD bajakan.

Sampai saat ini, yang sering dilakukan oleh para penegak hukum, khususnya Kepolisian, atas keberadaan hak kekayaan intelektual (hak cipta) dalam upaya penegakan hukum untuk menghentikan secara kilat kegiatan pembajakan masih berada pada sektor hilir dan pada sektor menengah. Di Indonesia pengaturan mengenai Hak Cipta diatur tersendiri dalam Undang-Undang Nomor 28 tahun 2014 tentang hak cipta.

\section{Permasalahan}

Dari uraian diatas maka permasalahan diketahui bahwa bagaimana penjualan bebas (compact disk) CD bajakan oleh pedagang kaki lima di Kota batam. Dalam hal ini akan diuraikan bagaimana penjualan bebas yang terjadi pada realititanya di masyarakat.

\section{METODELOGI}

Penelitian ini menggunakan penelitian normative yaitu undang-undang yang digunakan sebagai tolak ukur dalam hal menganalisa mengenai tinjauan yuridis terhadap CD bajakan yang beredar di masyarakat, dengan menggunakan pendekatan sosiologis untuk mendapatkan hasil yang ingin dicapai agar undang-undang yang ada diterapkan atau tidak di suatu masyarakat.

\section{PEMBAHASAN}

Perlindungan Hak Cipta di Indonesia telah dimulai dari zaman Hindia Belanda dengan berlakunya Auteurswet 1912, Staatsblad Nomor 600 Tahun 1912. Sejalan dengan berlakunya Undang-Undang Dasar Tahun 1945, keberlakuan Auteurswet 1912 tetap dipertahankan. Hingga pada Tahun 1982, Undang-Undang Hak Cipta pada masa kolonial tersebut dicabut dan diganti dengan Undang-Undang Nomor 6 Tahun 1982 tentang Hak Cipta Lembaran Negara Republik Indonesia Tahun 1982 Nomor 15. Perubahan yang terjadi di bidang ekonomi nasional dan internasional berkembang dengan cepat, sehingga untuk mengakomodasinya, perlindungan terhadap Hak Cipta perlu ditingkatkan.

Hak Cipta secara fundamental diatur dalam Pasal 28H ayat (4) Undang- Undang Dasar 1945, yakni: "Setiap orang berhak mempunyai hak milik pribadi dan hak milik tersebut tidak boleh diambil alih secara sewenang-wenang oleh siapapun”. Berdasarkan ketentuan ini Hak Cipta atau suatu hasil Ciptaan tidak dapat disebarluaskan tanpa sepengetahuan pemilik 
haknya. Ketentuan ini dipertegas dengan ketentuan Pasal 2 ayat (1) Undang-Undang Nomor 19 Tahun 2002 tentang Hak Cipta yakni: "Hak Cipta merupakan hak eksklusif bagi Pencipta atau Pemegang Hak Cipta untuk mengumumkan atau memperbanyak Ciptaannya, yang timbul secara otomatis setelah suatu Ciptaan dilahirkan tanpa mengurangi pembatasan menurut peraturan perundang-undangan yang berlaku."

Indonesia sebagaimana terdapat dalam Undang-Undang Nomor 19 tahun 2002 tentang Hak Cipta pada dasarnya menganut stelsel deklaratif, Hak Cipta diperoleh Pencipta secara otomatis (automatic protection) ketika suatu Ciptaan tersebut dilahirkan dalam suatu bentuk kesatuan yang nyata, yang memungkinkan perbanyakan hasil karya itu, sehingga dapat dilihat, dibaca, didengar atau dirasakan, seperti yang tertuang pada ketentuan Pasal 2 ayat (1) jo Pasal 12 ayat (3) Undang-Undang Nomor 19 tahun 2002 tentang Hak Cipta. Konsep perlindungan otomatis pertama kali diperkenalkan dalam Berne Convention.

Salah satu prinsip dari Berne Convention adalah Automatic Protection, menurut prinsip ini, pemberian perlindungan hukum harus diberikan secara langsung tanpa harus memenuhi syarat apapun. Jadi perlindungan Hak Cipta diberikan tanpa melalui pendaftaran. Prinsip ini tersirat dalam Pasal 35 ayat (4) Undang-Undang Nomor 19 tahun 2002 tentang Hak Cipta, Pendaftaran Ciptaan bukan merupakan suatu keharusan bagi Pencipta atau Pemegang Hak Cipta, dan timbulnya perlindungan suatu Ciptaan dimulai sejak Ciptaan itu ada atau terwujud dan bukan karena pendaftaran. Hal ini berarti suatu Ciptaan baik yang terdaftar maupun tidak terdaftar tetap dilindungi.

Adapun pembagian hak kekayaan industri terdiri dari:

1. Paten (patent) merupakan hak khusus yang diberikan negara kepada penemu atas hasil penemuannya di bidang teknologi, untuk selama waktu tertentu melaksanakan sendiri penemuannya tersebut atau memberikan pesetujuannya kepada orang lain untuk melaksanakannya.

2. Merk (Trademark) adalah tanda yang berupa gambar, nama, kata, huruf-huruf, angkaangka, susunan warna atau kombinasi dari unsur-unsur tersebut yang memiliki daya pembeda dan dipergunakan dalam kegiatan perdagangan barang dan jasa.

3. Rancangan (Industrial Design) dapat berupa rancangan produk industri, rancangan industri. Rancanangan industri adalah suatu kreasi tentang bentuk, konfigurasi, atau komposisi, garis atau warna, atau garis dan warna, atau gabungan daripadanya yang berbentuk tiga dimensi yang mengandung nilai estetika dan dapat diwujudkan dalam pola 
tiga dimensi atau dua dimensi serta dapat dipakai untuk menghasilkan suatu produk, barang atau komoditi industri dan kerajinan tangan.

4. Informasi Rahasia (Trade Secret) adalah informasi di bidabidang teknologi atau bisnis yang tidak diketahui oleh umum, mempunyai nilai ekonomi karena berguna dalam kegiatan usaha dan dijaga kerahasiannya oleh pemiliknya.

5. Indikasi Geografi (Geographical Indications) adalah tanda yang menunjukkn asal suatu barang yang karena faktor geografis (faktor alam atau faktor manusia dan kombinasi dari keduanya telah memberikan ciri dri kualitas tertentu dari barang yang dihasilkan).

6. Denah Rangkaian (Circuit Layout) yaitu peta (plan) yang memperlihatkan letak dan interkoneksi dari rangkaian komponen terpadu (integrated circuit), unsur yang berkemampun mengolah masukan arus listrik menjadi khas dalam arti arus, tegangan, frekuensi, serta prmeter fisik linnya.

7. Perlindungan Varietas Tanaman (PVT) adalah hak khusus yang diberikan negara kepada pemulia tanaman dan atau pemegang PVT atas varietas tanaman yang dihasilkannya untuk selama kurun waktu tertentu menggunakan sendiri varietas tersebut atau memberikan persetujun kepada orang atau badan hukum lain untuk menggunakannya.

Pendaftaran Ciptaan dilaksanakan pada Direktorat Jendaral Hak atas Kekayaan Intelektual (Ditjen HKI). Dalam keadaan ini, Ditjen HKI tidak bertanggung jawab atas terjadinya pemalsuan Ciptaan yang didaftarkan padanya, seperti yang diatur dalam Pasal 36 Undang-Undang Nomor 28 Tahun 20014 tentang Hak Cipta, yakni: "Pendaftaran Ciptaan dalam Daftar Umum Ciptaan tidak mengandung arti sebagai pengesahan atas isi, arti, maksud, atau bentuk dari Ciptaan yang didaftar". Hal ini tentu mengaburkan kepastian hukum yang diperoleh Pencipta asli suatu Ciptaan terhadap suatu Ciptaan yang didaftarkan. Boleh jadi sebagian kecil dari hasil Ciptaan itu benar-benar hasil Ciptaan seseorang yang mendaftarkan Ciptaannya tersebut, tetapi bisa saja sebagian yang lain merupakan tiruan dari suatu ide Ciptaan milik orang lain yang belum didaftarkan.

Fungsi pendaftaran Hak Cipta dimaksudkan untuk memudahkan pembuktian dalam hal terjadinya sengketa mengenai Hak Cipta. Seperti yang terdapat pada Penjelasan Pasal 5 ayat (2) Undang-Undang Nomor 28 Tahun 2014 tentang Hak Cipta, yakni: "Pada prinsipnya Hak Cipta diperoleh bukan karena pendaftaran, tetapi dalam hal terjadi sengketa di pengadilan mengenai Ciptaan yang terdaftar dan yang tidak terdaftar sebagaimana dimaksud pada ketentuan ayat (1) huruf a dan huruf b serta apabila pihak-pihak yang berkepentingan 
dapat membuktikan kebenarannya, hakim dapat menentukan pencipta yang sebenarnya berdasarkan pembuktian tersebut".

Pendaftaran tidak mutlak diharuskan, karena tanpa pendaftaran Hak Cipta tetap dilindungi, tetapi Ciptaan yang tidak didaftarkan akan lebih sukar dan lebih memakan waktu dalam hal pembuktiannya. Pendaftaran juga diharapkan dapat memberikan semacam kepastian hukum serta lebih memudahkan dalam prosedur pengalihan haknya.

Kota batam merupakan kota terbesar yang perputaran perdagangannya begitu cepat. Begitu banyak tempat-tempat berdagang yang dimanfaatkan oleh pedagang untuk mengais rejeki. Sebagai contoh pasar jodoh, pasar SP, pasar aviary dan banyak lagi. Perdagangan CD bajakan tidak hanya beredar di pasar, bahkan para pedagang memperjualkan dagangannya sampai ke mall-mall yang ada di batam dan itu diagggap biasa saja, belum lagi perdagangan bebas CD bajakan beredar di kaki lima jalan-jalan tertentu di kota batam.

Oleh karena itu peneliti merasa tertarik untuk menggali secara dalam menganai perdagangan yang selama ini menjual barang dagangan berupa CD bajakan yang sangat laris di kalangan masyarakat yang perekonomiannya menengah kebawah, tanpa adanya tindakan yang dapat membuat efek jera bagi penjual CD maupun pembajak atau penduplikat $C D$ tersebut.

Perlindungan hak cipta berlaku selama hidup pencipta dan terus berlangsung selama 70 tahun setelah pencipta meninggal dunia, terhitung mulai tanggal 1 Januari tahun berikutnya (Pasal 58 ayat 1). Sedangkan jika hak cipta tersebut dimiliki oleh badan hukum, maka berlaku selama 50 tahun sejak pertama kali dilakukan pengumuman. Berikut daftarnya:

a. buku, pamflet, dan semua hasil karya tulis lainnya;

b. ceramah, kuliah, pidato dan ciptaan sejenis lain;

c. alat peraga yang dibuat untuk kepentingan pendidikan dan ilmu pengetahuan;

d. lagu atau musik dengan atau tanpa teks;

e. drama, drama musikal, tari, koreografi, pewayangan, dan pantomim;

f. karya seni rupa dalam segala bentuk seperti lukisan, gambar, ukiran, kaligrafi, seni pahat, patung, atau kolase;

g. karya arsitektur;

h. peta; dan

i. karya seni batik atau seni motif lain.

Karya cipta yang berlaku selama 50 tahun sejak pertama kali pengumuman: 
a. karya fotografi;

b. potret;

c. karya sinematografi;

d. permainan video;

e. program komputer;

f. perwajahan karya tulis;

g. terjemahan, tafsiran, saduran, bunga rampai, basis data, adaptasi, aransemen, modifikasi, dan karya lain dari hasil transformasi;

h. terjemahan, adaptasi, aransemen, transformasi atau modifikasi ekspresi budaya tradisional;

i. kompilasi ciptaan atau data, baik dalam format yang dapat dibaca dengan program komputer atau media lainnya;

j. kompilasi ekspresi budaya tradisional selama kompilasi tersebut merupakan karya yang asli;

Kemudian untuk ciptaan berupa karya seni terapan, perlindungan hak cipta berlaku selama 25 tahun sejak pertama kali dilakukan pengumuman. Salah satunya adalah untuk para pengelola tempat perdagangan:

\section{Pasal 114:}

Setiap Orang yang mengelola tempat perdagangan dalam segala bentuknya yang dengan sengaja dan mengetahui membiarkan penjualan dan/atau penggandaan barang hasil pelanggaran Hak Cipta dan/atau Hak Terkait di tempat perdagangan yang dikelolanya sebagaimana dimaksud dalam Pasal 10, dipidana dengan pidana denda paling banyak Rp100.000.000,00 (seratus juta rupiah).

\section{Pasal 113:}

(1) Setiap Orang yang dengan tanpa hak melakukan pelanggaran hak ekonomi sebagaimana dimaksud dalam Pasal 9 ayat (1) huruf i untuk Penggunaan Secara Komersial dipidana dengan pidana penjara paling lama 1 (satu) tahun dan/atau pidana denda paling banyak Rp100.000.000 (seratus juta rupiah). 
(2) Setiap Orang yang dengan tanpa hak dan/atau tanpa izin Pencipta atau pemegang Hak Cipta melakukan pelanggaran hak ekonomi Pencipta sebagaimana dimaksud dalam Pasal 9 ayat (1) huruf c, huruf d, huruf f, dan/atau huruf h untuk Penggunaan Secara Komersial dipidana dengan pidana penjara paling lama 3 (tiga) tahun dan/atau pidana denda paling banyak Rp500.000.000,00 (lima ratus juta rupiah).

(3) Setiap Orang yang dengan tanpa hak dan/atau tanpa izin Pencipta atau pemegang Hak Cipta melakukan pelanggaran hak ekonomi Pencipta sebagaimana dimaksud dalam Pasal 9 ayat (1) huruf a, huruf b, huruf e, dan/atau huruf g untuk Penggunaan Secara Komersial dipidana dengan pidana penjara paling lama 4 (empat) tahun dan/atau pidana denda paling banyak Rp1.000.000.000,00 (satu miliar rupiah).

(4) Setiap Orang yang memenuhi unsur sebagaimana dimaksud pada ayat (3) yang dilakukan dalam bentuk pembajakan, dipidana dengan pidana penjara paling lama 10 (sepuluh) tahun dan/atau pidana denda paling banyak Rp4.000.000.000,00 (empat miliar rupiah).

Kepentingan hukum adalah mengurusi hak dan kepentingan manusia, sehingga hukum memiliki otoritas tertinggi untuk menentukan kepentingan manusia yang perlu diatur dan dilindungi. Perlindungan hukum harus melihat tahapan yakni perlindungan hukum lahir dari suatu ketentuan hukum dan segala peraturan hukum yang diberikan oleh masyarakat yang pada dasarnya merupkan kesepakatan masyarakat tersebut untuk mengatur hubungan perilaku antara anggota-anggota masyarakat dan antara perseorangan dengan pemerintah yang dianggap mewakili kepentingan masyarakat. ${ }^{1}$

Menurut Satjipto Rahardjo, Perlindungan hukum adalah memberikan pengayoman terhadap hak asasi manusia (HAM) yang dirugikan orang lain dan perlindungan itu diberikan kepada masyarakat agar dapat menikmati semua hak-hak yang diberikan oleh hukum. ${ }^{2}$

Selanjutnya menurut Phillipus M. Hadjon bahwa perlindungan hukum bagi rakyat sebagai tindakan pemerintah yang bersifat preventif dan resprensif. Perlindungan Hukum yang preventif bertujuan untuk mencegah terjadinya sengketa, yang mengarahkan tindakan pemerintah bersikap hati-hati dalam pengambilan keputusan berdasarkandiskresi dan

\footnotetext{
${ }^{1}$ Satjipto Raharjo, Ilmu Hukum, Bandung: PT.Citra Aditya Bakti, 2000, hlm.53

${ }^{2}$ Ibid, hlm.69
} 
perlindungan yang resprensif bertujuan untuk mencegah terjadinya sengketa, termasuk penanganannya di lembaga peradilan. ${ }^{3}$

Konsep perlindungan otomatis pertama kali diperkenalkan dalam Berne Convention. Salah satu prinsip dari Berne Convention adalah Automatic Protection, menurut prinsip ini, pemberian perlindungan hukum harus diberikan secara langsung tanpa harus memenuhi syarat apapun. Jadi perlindungan Hak Cipta diberikan tanpa melalui pendaftaran. Prinsip ini tersirat dalam Pasal 35 ayat (4) Undang-Undang Nomor 19 Tahun 2002 tentang Hak Cipta, Pendaftaran Ciptaan bukan merupakan suatu keharusan bagi Pencipta atau Pemegang Hak Cipta, dan timbulnya perlindungan suatu Ciptaan dimulai sejak Ciptaan itu ada atau terwujud dan bukan karena pendaftaran. Hal ini berarti suatu Ciptaan baik yang terdaftar maupun tidak terdaftar tetap dilindungi.

Definisi hukum adalah sebagai berikut: "Hukum ialah peraturan-peraturan yang bersifat memakasa, yang menentukan tingkah laku manusia dalam lingkungan masyarakat yang dibuat oleh badan-badan resmi yang berwajib, pelanggaran mana terhadap peraturanperaturan tadi berakibat diambilnya tindakan, yaitu dengan hukuman tertentu." ${ }^{4}$ Indonesia memiliki beberapa jenis hukum, salah satunya ialah Hukum Hak Cipta. Hak Cipta adalah hak eksklusif pencipta yang timbul secara otomatis berdasarkan prinsip deklaratif setelah suatu ciptaan diwujudkan dalam bentuk nyata tanpa mengurangi pembatasan sesuai dengan ketentuan peraturan perundang-undangan. ${ }^{5}$

Hak eksklusif adalah hak yang semata-mata diperuntukkan bagi pemegangnya sehingga tidak ada pihak lain yang boleh memanfaatkan hak tersebut tanpa seizin dari pencipta. Hak eksklusif ini dilaksanakan tanpa mengurangi pembatasan-pembatasan hak cipta. ${ }^{6}$ Hak cipta merupakan salah satu bagian dari sekumpulan hak yang dinamakan Hak Kekayaan Intelektualitas (HKI) yang pengaturannya terdapat dalam ilmu hukum dan dinamakan Hukum HKI, meliputi suatu bidang hukum yang membidangi hak-hak yuridis atas karya-karya atau cipta hasil oleh pikiran manusia bertautan dengan kepentingan-kepentingan bersifat ekonomi dan moral. ${ }^{7}$ Hak Kekayaan Intelektual dapat diartikan sebagai hak atas

\footnotetext{
${ }^{3}$ Ibid, hlm.54
}

${ }^{4}$ C.T.S. Kansil dan Christine S.T. Kansil, Pengantar Ilmu Hukum Indonesia, Jakarta: PT Rineka Cipta, 2011, hlm. 34

${ }^{5}$ Pasal 1 angka 1, Undang-Undang Nomor 28 Tahun 2014 Tentang Hak Cipta

${ }^{6}$ Gatot Supramono, op. cit, hlm . 9

${ }^{7}$ Eddy Damian, Hukum Hak Cipta, Bandung: PT. Alumi, 2009. hlm. 29 
kepemilikan terhadap karya-karya yang timbul atau lahir karena adanya kemampuan intelektualitas manusia dalam bidang ilmu pengetahuan dan teknologi.

Hak cipta terdiri dari hak moral dan hak ekonomi, sebagaimana dimaksud UU Hak Cipta 2014 hak moral merupakan hak yang melekat secara abadi pada diri pencipta untuk:

1. Tetap mencantumkan atau tidak mencantumkan namanya pada salinan sehubungan dengan pemakaian Ciptaannya untuk umum;

2. Menggunakan nama aliasnya atau samarannya

3. Mengubah Ciptaannya sesuai dengan kepatutan dalam masyarakat;

4. Mengubah judul dan anak judul Ciptaan; dan

5. Mempertahankan haknya dalam hal terjadi distorsi ciptaan, mutilasi ciptaan, modifikasi Ciptaan, atau hal yang bersifat merugikan kehormatan diri atau reputasinya.

Sedangkan hak ekonomi menurut UU Hak Cipta tahun 2014 adalah hak eksklusif pencipta atau pemegang hak cipta untuk mendapatkan manfaat ekonomi atas ciptaan. Hak tersebut meliput 8 hal, yaitu:

1. Penerbitan ciptaan

2. Pengadaan ciptaan dalam segala bentuknya

3. Penerjemahan ciptaan;

4. Pengadaptasian, pengaransemenan, atau pentransformasian ciptaan

5. Pendistribusian atau salinannya;

6. pertunjukan Ciptaan;

7. Pengumuman Ciptaan; Komunikasi Ciptaan dan penyewaan Ciptaan.

Hak Kekayaan Intelektual dapat diartikan sebagai hak atas kepemilikan terhadap karya-karya yang timbul atau lahir karena adanya kemampuan intelektualitas manusia dalam bidang ilmu pengetahuan dan teknologi. Hak cipta terdiri dari hak moral dan hak ekonomi, sebagaimana dimaksud UU Hak Cipta 2014 hak moral merupakan hak yang melekat secara abadi pada diri pencipta untuk:

1. Tetap mencantumkan atau tidak mencantumkan namanya pada salinan sehubungan dengan pemakaian Ciptaannya untuk umum;

2. Menggunakan nama aliasnya atau samarannya

3. Mengubah Ciptaannya sesuai dengan kepatutan dalam masyarakat;

4. Mengubah judul dan anak judul Ciptaan; dan 
5. Mempertahankan haknya dalam hal terjadi distorsi ciptaan, mutilasi ciptaan, modifikasi Ciptaan, atau hal yang bersifat merugikan kehormatan diri atau reputasinya.

Sedangkan hak ekonomi menurut UU Hak Cipta tahun 2014 adalah hak eksklusif pencipta atau pemegang hak cipta untuk mendapatkan manfaat ekonomi atas ciptaan. Hak tersebut meliput 8 hal, yaitu:

1. Penerbitan ciptaan

2. Pengadaan ciptaan dalam segala bentuknya

3. Penerjemahan Ciptaan;

4. Pengadaptasian, pengaransemenan, atau pentransformasian ciptaan

5. Pendistribusian atau salinannya;

6. Pertunjukan Ciptaan;

\section{Pengumuman Ciptaan;}

8. Komunikasi Ciptaan dan penyewaan Ciptaan.

Hak Kekayaan Intelektual (HKI) merupakan padanan kata yang biasa digunakan untuk Intellectual Property Rights (IPR). ${ }^{8}$ Istilah atau terminologi Hak Kekayaan Intelektual (HKI) digunakan untuk pertama kalinya pada tahun 1790. Fichte yang pada tahun 1793 mengatakan tentang hak milik dari si pencipta ada pada bukunya. Yang dimaksud dengan hak milik disini bukan buku sebagai benda, tetapi buku dalam pengertian isinya. ${ }^{9}$ Istilah HKI terdiri dari tiga kata kunci, yaitu Hak, Kekayaan, dan Intelektual Adapun kekayaan intelektual merupakan kekayaan atas segala hasil produksi kecerdasan daya pikir seperti teknologi, pengetahuan, seni, sastra, gubahan lagu, karya tulis, karikatur, dan lain-lain yang berguna untuk manusia. ${ }^{10}$

Secara garis besar HKI dibagi menjadi dua bagian, yaitu1: ${ }^{11}$

1. Hak Cipta (Copyrights)

2. Hak Kekayaan Industri (Industrial Property Rights)

Istilah Copyright (Hak Cipta) pertama kali dikemukakan dalam Berne Convention yang diadakan Tahun 1886. Dalam Berne Convention, pengertian Hak Cipta tidak dirumuskannya dalam Pasal tersendiri namun tersirat dalam Article 2, Article 3, Article 11

\footnotetext{
${ }^{8}$ Syafrinaldi, Hukum Tentang Perlindungan Hak Milik Intelektual Dalam Menghadapi Era Globalisasi, Jakarta, 2010, hlm. 3

${ }^{9}$ Ibid

${ }^{10}$ Sutedi A, Hak Atas Kekayaan Intelektual, Sinar Grafika, Jakarta, 2009, hlm. 6

${ }^{11}$ Buku Panduan Hak Kekayaan Intelektual, Ditjen HKI, 2006, hlm. 3
} 
dan Article 13 yang isinya diserap dalam Pasal 2 jo Pasal 10 Auteurswet 1912. ${ }^{12}$ Dalam Auteurswet 1912 Pasal 1 diatur bahwa: "Hak Cipta adalah hak tunggal dari Pencipta atau hak dari yang mendapat hak tersebut, atas hasil Ciptaannya dalarn lapangan kesusastraan, pengetahuan dan kesenian, untuk mengumumkan dan memperbanyak dengan mengingat pembatasan-pembatasan yang ditentukan oleh Undang-Undang."

Pasal 1 angka 1 Undang-Undang Nomor 28 tahun 2014 tentang Hak Cipta, mengatur: "Hak Cipta adalah hak eksklusif Pencipta yang timbul secara otomatis berdasarkan prinsip deklaratif setelah suatu ciptaan diwujudkan dalam bentuk nyata tanpa mengurangi pembatasan sesuai dengan ketentuan peraturan perundang- undangan". Berdasarkan pengertian Hak Cipta menurut Pasal 1 angka 1 Undang-Undang Nomor 28 tahun 2014 tentang Hak Cipta, arti dari hak eksklusif adalah hak yang semata-mata diperuntukan bagi pencipta, sehingga tidak ada pihak lain yang boleh memanfaatkan hak tersebut tanpa izin penciptanya.

Berkaitan dengan ketentuan Pasal 1 angka 1 Undang-Undang Nomor 28 tahun 2014 tentang Hak Cipta, maka diuraikan lebih lanjut mengenai pengertian dan sifat Hak Cipta itu: ${ }^{13}$

1. Hak Cipta merupakan hak yang bersifat khusus, istimewa atau eksklusif (Exclusive Rights) yang diberikan kepada Pencipta atau Pemegang Hak Cipta. Ini berarti, orang lain tidak boleh menggunakan hak tersebut, kecuali dengan izin Pencipta atau Pemegang Hak Cipta yang bersangkutan;

2. Hak yang bersifat khusus meliputi hak Pencipta atau Pemegang Hak Cipta untuk mengumumkan Ciptaannya, memperbanyak Ciptaannya dan memberi izin kepada orang lain untuk mengumumkan atau memperbanyak hasil Ciptaannya tersebut;

3. Dalam pelaksanaan untuk mengumumkan atau memperbanyak Ciptaannya, baik Pencipta, Pemegang Hak Cipta, maupun orang lain yang diberi izin, harus dilakukan menurut peraturan perundang-undangan yang berlaku.

4. Hak Cipta dianggap sebagai benda bergerak yang bersifat immaterial yang dapat beralih atau dialihkan kepada orang lain.

5. Lokasi perdagangan CD bajakan di Kota Batam secara terang-terangan sudah menjadi pemandangan yang umum bagi masyarakat. Hampir banyak lokasi menjual semua

\footnotetext{
${ }^{12}$ Ok. Saidin, Aspek Hukum Kekayaan Intelektual (Intellectual Property Right), Rajawali Pers, Jakarta, 2004, hlm. 61

${ }^{13}$ Rachmadi Usman,Hukum HAKI: Perlindungan dan Dimensi Hukumnya, Alumni, Bandung, 2003, hlm. 86
} 
pusat-pusat pertokoan dan perbelanjaan, seperti pasar-pasar dan mall. Lokasi tersebut dipilih oleh para pedagang sebab lokasi sangat strategis dikarenakan tidak pernah sepi pengunjung.

Para pedagang CD bajakan ini latar belakang pendidikannya rata-rata berpendidikan sekolah dasar hingga sekolah menengah atas. Dari segi latar belakang sosial ekonominya mereka dapat dikategorikan sebagai masyarakat bawah. Para pedagang CD bajakan ini rata-rata telah melakukan perdagangan mereka sudah cukup lama, bukan hanya setahun ataupun dua tahun tetapi bertahun-tahun. Perdagangan ini dianggap mudah dan banyak pelanggan yang lebih tertarik untuk membeli CD bajakan dikarenakan beberapa faktor yaitu salah satunya harga terjangkau dibandingkan $\mathrm{CD}$ asli.

\section{KESIMPULAN}

Pada dasarnya jual beli adalah kegiatan yang lazim dilakukan masyarakat, yang menjadi masalah ketika jual beli yang dilakukan objeknya tidak halal sesuai dengan Pasal 5 ayat (2) Undang-Undang Nomor 28 Tahun 2014 tentang Hak Cipta, yakni: "Pada prinsipnya Hak Cipta diperoleh bukan karena pendaftaran, tetapi dalam hal terjadi sengketa di pengadilan mengenai Ciptaan yang terdaftar dan yang tidak terdaftar sebagaimana dimaksud pada ketentuan ayat (1) huruf a dan huruf $b$ serta apabila pihak-pihak yang berkepentingan dapat membuktikan kebenarannya, hakim dapat menentukan pencipta yang sebenarnya berdasarkan pembuktian tersebut". Penjualan bebas CD bajakan merupakan tindakan pidana yang harus diberantas, dengan adanya Undang-Undang Hak Cipta mengatur mengenai pembajakan semakin luas beredar di pasaran.

Dalam hal penjualan atau peredaran CD yang marak beredar di masyarakat dengan mudahnya didapat dan terjangkau bahwkan cenderung murah dibanding harga asli atau original. Dengan adanya undang-undang hak cipta sebagai salah satu upaya pemerintah untuk memberantas pembajakan yang semakin hari semakin luas beredar. Batam merupakan pusat perekonomian yang pesat terhadap perputaran jual beli termasuk penjualan CD bajakan, dikarenakan mudahnya konsumen atau masyarakat mendapatkan, dalam hal ini dari sisi harga dan juga tempat untuk membeli CD tersebut.

Dengan adanya undang-undang hak cipta diharapkan para produsen pembuat CD dan juga pemilik karya tidak akan waa-was atau khawatir karya atau ciptaannya diperjual belikan tanpa ijin dan dengan mudahnya oknum memperbanyak kepingan. Kerugian yang didapat 
dalam hal penjualan CD bajakan khususnya di kota batam harus ada kontrol dari aparat Negara agar kerugian materiil dan immaterial pencipta tidak semakin banyak.

\section{DAFTAR PUSTAKA}

Ditjen HKI. (2006). Buku Panduan Hak Kekayaan Intelektual

C.T.S. Kansil dan Christine S.T. Kansil. (2011). Pengantar Ilmu Hukum Indonesia, Jakarta: PT Rineka Cipta.

Damian, Eddy. (2009). Hukum Hak Cipta. Bandung: PT. Alumi.

Saidin, Ok. (2004). Aspek Hukum Kekayaan Intelektual (Intellectual Property Right). Jakarta: Rajawali Pers.

Raharjo, Satjipto. (2000). Ilmu Hukum. Bandung: PT.Citra Aditya Bakti.

A, Sutedi. (2009). Hak Atas Kekayaan Intelektual. Jakarta: Sinar Grafika,

Usman, Rachmadi. (2003). Hukum HAKI: Perlindungan dan Dimensi Hukumnya. Bandung: Alumni.

Syafrinaldi. (2010). Hukum Tentang Perlindungan Hak Milik Intelektual Dalam Menghadapi Era Globalisasi. Jakarta.

Undang-Undang Nomor 28 Tahun 2014 Tentang Hak Cipta 